\title{
Effect of teatcup removal settings on milking efficiency and milk quality in a pasture-based automatic milking system
}

\author{
P. Silva Boloña, ${ }^{1 *}$ D. J. Reinemann, ${ }^{2}$ and J. Upton ${ }^{3}$ \\ ${ }^{1}$ Department of Dairy Science, University of Wisconsin, Madison 53706 \\ ${ }^{2}$ Biological Systems Engineering Department, University of Wisconsin, Madison 53706 \\ ${ }^{3}$ Animal and Grassland Research and Innovation Centre, Teagasc Moorepark Fermoy, Co. Cork, Ireland P61 C996
}

\section{ABSTRACT}

In automatic milking systems (AMS), it is important to maximize the amount of milk harvested per day to increase profitability. One strategy to achieve this goal is to reduce the time it takes to milk each cow. Several studies in conventional milking systems have shown that milking time can be reduced by increasing the milk flow rate at which the teatcup is removed. One study analyzed the effect of increasing the milk flow switch point on milking time in a confinement AMS. No research has been conducted on teatcup removal settings in pasture-based automatic milking systems. Furthermore, not all AMS remove the teatcups based on absolute milk flow rate $(\mathrm{kg} / \mathrm{min})$; hence, it is important to study alternative strategies. The aim of this experiment was to measure the effect of 3 novel teatcup removal strategies on box time (time in the AMS), milking time, somatic cell count (SCC), and milk production rate of cows milked in a pasture-based automatic milking system. Each teatcup removal strategy in this study was applied for a period of 1 wk to 1 of 3 groups of cows and then switched to the following group until cows had transitioned through all treatments. The teatcup removal strategies consisted of removing the teatcup when the quarter flow rate fell below $20 \%$ of the quarter rolling average milk flow rate (TRS20), when quarter milk flow rate was below $30 \%$ of the rolling average milk flow rate (TRS30), and when quarter milk flow rate dropped below $50 \%$ of the rolling average milk flow rate (TRS50). A limit prevented teatcup removal if the calculated milk flow rate for teatcup removal was above $0.5 \mathrm{~kg} / \mathrm{min}$. This limit was in place for all treatments; however, it only affected the TRS50 treatment. The TRS30 strategy had 9-s shorter milking time and 11-s shorter box time than the TRS20 removal strategy. The TRS50 strategy had 8-s shorter

Received October 12, 2018.

Accepted May 21, 2019.

*Corresponding author: psilva2@wisc.edu milking time and 9-s shorter box time than the TRS20 teatcup removal strategy. There was no significant difference in milking time or box time between the TRS30 and TRS50 teatcup removal strategies, probably due to the large variability in milk flow rate at teatcup removal. The TRS20 and TRS30 strategies did not differ in SCC or milk production rate. The $0.5 \mathrm{~kg} / \mathrm{min}$ limit, which affected roughly $25 \%$ of milkings in the TRS50 treatment, may have distorted the effect that this setting had on milk time, box time, milk production rate, or SCC. The difference in box time for the TRS30 and TRS50 strategies could allow for more than 3 extra milkings per day.

Key words: teatcup removal, automatic milking, milking efficiency, somatic cell count

\section{INTRODUCTION}

In automatic milking systems (AMS), it is important to maximize efficiency to have an earlier return on investment. One aspect of efficiency in AMS is milking capacity, which is the number of milkings performed by the robot in $1 \mathrm{~d}$ (Castro et al., 2012). To maximize milking capacity in AMS, 2 of the main strategies are (1) managing cow behavior to achieve a steady stream of cows presenting themselves to be milked in the robot and (2) reducing the time it takes for each milking to be performed. In a study conducted by Castro et al. (2012), the most important factors determining the milk yield per robot per year were the average milk flow rate during a single milking and the number of cows milked per robot per day. These 2 factors explained $87 \%$ of the variation in milk yield per robot per year. The researchers found that if the average milk flow rate increased by $0.1 \mathrm{~kg} / \mathrm{min}$, another $32,000 \mathrm{~kg}$ of milk could be harvested per robot per year. Furthermore, faster milking could facilitate more cows per automatic milking unit or more milkings per cow per day, which in turn may have a positive effect on milk harvested, allowing earlier economic returns of the system. Castro et al. (2012) estimated that an additional $8,200 \mathrm{~kg}$ of 
milk per year could be harvested if 1 extra cow was milked in the robot.

One strategy explored for reducing milking time, mainly studied in conventional milking systems, is to increase the milk flow rate at which clusters are removed (Jago et al., 2010; Burke and Jago, 2011; Edwards et al., 2013a). A common farmer concern with this strategy is leaving milk in the udder and the effect it could have on milk production, mastitis, and SCC. A study by Schalm and Mead (1943) found that milking the udder incompletely increased the number of clinical mastitis cases in cows chronically infected with a contagious pathogen (Streptococcus agalactiae). No effect was shown for cows free from infection. Penry et al. (2017) saw a small increase in SCC (26,300-48,300 cells $/ \mathrm{mL}$ ) for quarters that were severely undermilked, with approximately $30 \%$ of the milk left in the quarter. However, Edwards et al. (2013a) showed that increasing the cluster removal switch point from 0.2 to $0.8 \mathrm{~kg} / \mathrm{min}$ at the udder level for a period of 9 wk reduced milking time by 18 to $26 \%$ without affecting SCC or milk production variables. Burke and Jago (2011) found that milking duration was reduced by $11 \%$ by changing unit removal settings from 0.2 to $0.4 \mathrm{~kg} / \mathrm{min}$ at the udder level over a 35 -wk period without negatively affecting SCC; however, a significant slight decrease in milk yield $(1 \%)$ was observed. Fewer studies have examined teatcup removal settings in automatic milking. In a short-term study by Krawczel et al. (2017), the teatcup removal level was increased from 0.06 to $0.48 \mathrm{~kg} / \mathrm{min}$ at the quarter level without any negative effects on milk yield or SCC while reducing total milking time by $0.9 \mathrm{~min}$. However, the milking interval was maintained at around $8 \mathrm{~h}$ on average by frequently fetching cows, which is not the usual scenario in grazing robotic dairy farms. A study conducted in an AMS (Mollenhorst et al., 2011) showed that, when corrected for other variables, increased milking interval was associated with only a slight increase in SCC, whereas the variation in milking interval had a much larger effect.

There is a lack of knowledge on how different teatcup removal settings affect milking time, milk yield, and milk quality in pasture-based AMS. In conventional milking systems, milking interval is fixed. However, cows managed in pasture-based AMS usually have greater and more variable milking intervals than conventional milking and indoor AMS (Davis et al., 2005). This causes variable degrees of udder filling at the time of milking, which has been shown to affect the start of milk ejection (Bruckmaier and Hilger, 2001) and potentially milking time. Therefore, evaluating the effect of teatcup removal settings on milking time in pasturebased AMS could provide new knowledge to milking management research. Additionally, some robotic milk- ing machines use a flow rate teatcup removal switch point based on an absolute value $(\mathrm{kg} / \mathrm{min})$, whereas others use different strategies such as a percentage of the average milk flow rate. To our knowledge, no studies have evaluated a percentage of the milk flow rate as a decision for the end of milking. Therefore, it is important to evaluate different strategies available to get a better understanding of the effect of teatcup removal level on milking time and milk quality. The objective of this study was to quantify the effects of 3 novel end-of-milking criteria on box time (time in the AMS), milking time, average milk flow rate, maximum milk flow rate, milk production rate, and SCC.

\section{MATERIALS AND METHODS}

This experiment was carried out at the research facility at Teagasc Moorepark, Cork, Ireland, between May 25 and June 12, 2017. The research farm operated a spring-calving, grass-based AMS. The farm was divided into 4 areas, and in each area a grazing allocation was made available daily. Each allocation was available for $6 \mathrm{~h} / \mathrm{d}$, one after the other, for cows to transition through. In the robot, $1 \mathrm{~kg}$ of concentrate feed/d was provided. Eighty-six cows were milked using a single Astronaut A4 robotic milking system (Lely, Maassluis, the Netherlands). The system vacuum level was set to $43 \mathrm{kPa}$, pulsation ratio of 65:35, and pulsation rate of $60 \mathrm{pulses} / \mathrm{min}$.

The AMS calculates milk flow rates every second and with these measurements generates a 30 -s rolling average that is updated every second. The teatcup removal algorithm compares the last milk flow rate calculated with a percentage of the rolling average milk flow rate and makes the decision whether to remove the teatcup. One value below the milk flow switch point starts the teatcup removal process; however, the teatcups are not removed until milk flow rate has remained below that switch point for a pre-set amount of time (in seconds). If milk flow rate increases above the switch point during that time (also referred to as delay time), then the teatcup will not be removed and the milk flow switch point will be calculated again. Additionally, the AMS has a criterion for minimum milking time (where no teatcup removal decisions are made), which consists of keeping the teatcups on for at least twice the time passed between teatcup attachment and the start of milk flow (called dead milk time).

\section{Experimental Treatments}

The treatments consisted of 3 teatcup removal settings (TRS). One removal setting consisted of removing the teatcup when the quarter flow rate fell below $20 \%$ 
of the quarter rolling average milk flow rate (TRS20). The second treatment removed teatcups when quarter milk flow rate dropped below $30 \%$ of the rolling average milk flow rate (TRS30), and the third teatcup removal strategy was when quarter milk flow rate dropped below $50 \%$ of the rolling average milk flow rate (TRS50). All settings had a 3-s delay, meaning that units were removed $3 \mathrm{~s}$ after reaching the milk flow rate switch point. There was a maximum teatcup removal flow rate limit of $0.5 \mathrm{~kg} / \mathrm{min}$, which prevented teatcup removal if the quarter milk flow rate was above this limit. It was not possible to change the $0.5 \mathrm{~kg} / \mathrm{min}$ limit in this AMS. Before the start of the experiment, cows were milked using the TRS30 setting. Cup removal settings are applicable on an individual cow level, but the decision is quarter based. Because of this, the experimental unit for this experiment was the cow.

Cows were divided into 3 groups, which transitioned through all 3 treatments in a crossover design. Each treatment period consisted of $1 \mathrm{wk}$, with the last $2 \mathrm{~d}$ of each treatment period being used for milk sampling to obtain individual SCC data. The treatment period was selected considering that the effect of the TRS should be noticeable very rapidly after the setting is applied, similar to what was implemented in the cognate studies by Edwards et al. (2013b) and Krawczel et al. (2017).

Milk samples were collected using the Shuttle (Lely), and SCC was measured using a Fossomatic machine (Foss, Hillerød, Denmark). Milk samples were treated in the Shuttle using Broad Spectrum Microtabs (Advanced Instruments Inc., Norwood, MA) in each milk sampling bottle to preserve the sample until it was transported to the milk testing laboratory.

\section{Cow Selection}

Cows were suitable for enrollment in the study provided they did not present a clinical case of mastitis during the 2017 milking season and had an udder level SCC of $<200,000$ cells $/ \mathrm{mL}$ at a milk recoding test carried out $1 \mathrm{wk}$ before the experimental treatments started. A total of 75 cows were enrolled in the experiment and consisted of 68 Holstein Friesians, 5 Jerseys, and 2 Norwegian Reds. Their average DIM at the start of the experiment was $82 \mathrm{~d}(\mathrm{SD}=27)$. Parity ranged from 1 to 7 with a mean of $3.3(\mathrm{SD}=1.6$; see Table $1)$. Cows were blocked based on parity $(1$ and $>1)$, breed (Holstein Friesian, Jersey, and Norwegian Red), and maximum milk flow rate $(<3.5$ and $\geq 3.5 \mathrm{~kg} / \mathrm{min})$. After blocking, cows in each block were randomly assigned to 1 of the 3 treatment groups. Groups were randomly assigned to 1 of the 3 treatments at the start of the experiment, and they transitioned through the remaining treatments as shown in Table 2 .
Table 1. Summary of several herd and milking parameters during the experimental period

\begin{tabular}{lcc}
\hline Parameter $^{1}$ & Mean & SD \\
\hline Lactation no. & 3.3 & 1.6 \\
DIM start & 82 & 27 \\
DIM end & 107 & 26 \\
Milk yield/milking (kg) & 13.3 & 4.2 \\
Milk yield/d (kg) & 19.3 & 8 \\
Box time (s) & 419 & 137 \\
Milk time (s) & 343 & 136 \\
Milking interval (h) & 14.1 & 4.3 \\
\hline
\end{tabular}

${ }^{1}$ DIM start and end = DIM at the start and end of the trial period, respectively; milking interval $=$ time $(\mathrm{h})$ since the last milking. This value does not consider a 24 -h period and therefore is independent of whether the last milking occurred on the previous day or on the same day.

\section{Data Management and Statistical Analysis}

Milking data were retrieved from the AMS farm management software (Lely T4C) and were combined with the milk testing laboratory SCC results. Because milk sampling causes an increase in box time, only the first $5 \mathrm{~d}$ of each treatment period were used for the analysis of milking performance outcome variables. Three cows (1 from each group) were removed from the data set because of erratic milking behavior with very high milking times $(>15 \mathrm{~min})$ and were considered unsuitable for milking in robotic systems. Because this was the first season of the AMS, no prior selection was made for cows entering the robotic herd. Maximum milk flow rate was calculated as the maximum 30-s rolling average. Cow milk production rate $(\mathrm{kg} / \mathrm{h})$ was calculated by dividing milk production for each milking by the milking interval. Because there was no information on milk flow rate curves, an estimation of milk flow rate at teatcup removal was calculated as the average milk flow rate multiplied by the teactup removal setting (e.g., for TRS30, the calculation was average milk flow rate $\times$ $0.3)$. Somatic cell counts were $\log _{10}$ transformed due to the highly skewed nature of these data. Two cows developed clinical mastitis during the experiment and were taken out of the final analysis. Both cows were from group 3 (one case during the TRS50 treatment and the second during the TRS20 treatment).

Table 2. Treatment sequence for the groups in the experiment ${ }^{1}$

\begin{tabular}{lccc}
\hline Group & Week 1 & Week 2 & Week 3 \\
\hline 1 & TRS30 & TRS20 & TRS50 \\
2 & TRS20 & TRS50 & TRS30 \\
3 & TRS50 & TRS30 & TRS20 \\
\hline
\end{tabular}

${ }^{1}$ TRS20 $=$ teatcup removal at $20 \%$ of the average flow rate; TRS30 $=$ teatcup removal at $30 \%$ of the average flow rate; TRS50 = teatcup removal at $50 \%$ of the average flow rate. 
Table 3. Effect of teatcup removal setting on several parameters related to milking efficiency and SCC

\begin{tabular}{lccccc}
\hline & \multicolumn{3}{c}{ Treatment $^{1}$} & & \\
\cline { 2 - 4 } Parameter & TRS20 & TRS30 & TRS50 & SEM & P-value \\
\hline Average milk flow rate (kg/min) & 2.50 & 2.53 & 2.53 & 0.28 & 0.27 \\
Maximum milk flow rate (kg/min) & 3.71 & 3.69 & 3.73 & 0.43 & 0.45 \\
Milk production rate (kg/h) & 0.84 & 0.84 & 0.83 & 0.1 & 0.2 \\
Milk production/milking (kg) & 11.9 & 11.9 & 11.7 & 1.3 & 0.4 \\
Milk production/d (kg) & 19.4 & 19.3 & 19.1 & 2.1 & 0.8 \\
Box time (s) & $429^{\mathrm{a}}$ & $418^{\mathrm{b}}$ & $420^{\mathrm{b}}$ & 36.8 & 0.01 \\
Milk time (s) & $350^{\mathrm{a}}$ & $341^{\mathrm{b}}$ & $342^{\mathrm{b}}$ & 36.8 & 0.02 \\
Log $_{10}$ SCC & 4.55 & 4.5 & 4.51 & 0.05 & 0.33 \\
\hline
\end{tabular}

${ }^{a, b}$ Different letters within a row indicate significant differences at the $\alpha=0.05$ level.

${ }^{1}$ TRS2 0 = teatcup removal at $20 \%$ of the average flow rate; TRS30 = teatcup removal at $30 \%$ of the average flow rate; TRS50 = teatcup removal at $50 \%$ of the average flow rate.

\section{Statistical Analysis}

The dependent variables assessed were box time (BT), milk time (MT), average milk flow rate (AMF), maximum milk flow rate (MMF), milk production rate (MPR), and $\log _{10}$ SCC. A backward elimination process was followed to find the proper variables to explain our dependent outcomes. The MIXED procedure of SAS 9.4 (SAS Institute Inc., Cary, NC) was used with the following model statement. For MT, BT, AMF, and MMF, the model was

$$
\begin{aligned}
y & =\text { milk yield }+ \text { week }+ \text { treatment }+ \text { block } \\
& + \text { group }+ \text { block } \times \text { group }+ \text { cow }(\text { group }),
\end{aligned}
$$

where $y$ represented the following dependent variables: MT (s), the time from first teatcup attachment to last teatcup removal; BT (s), time that the cow was present in the AMS; AMF ( $\mathrm{kg} / \mathrm{min})$, average milk flow rate; and MMF $(\mathrm{kg} / \mathrm{min})$, peak or maximum milk flow rate (the maximum 30-s rolling average).

For $\log _{10}$ SCC, the model was

$$
\begin{aligned}
& \log _{10} \mathrm{SCC}=\text { milk yield }+ \text { lactation }+ \text { week } \\
& + \text { treatment }+ \text { group }+ \text { block }+ \text { block } \\
& \times \text { group }+ \text { cow }(\text { group }) .
\end{aligned}
$$

For milk production rate (milk production from the last milking divided by the milking interval), the model was

$$
\begin{aligned}
\text { MPR } & =\text { week }+ \text { treatment }+ \text { group }+ \text { block } \\
& + \text { block } \times \text { group }+ \text { cow }(\text { group }) .
\end{aligned}
$$

Week (1, 2, 3), treatment (TRS20, TRS30, TRS50), block (1 to 8), group $(1,2,3)$, and cow were declared as class variables. Week, treatment, lactation, and milk yield were classified as fixed effects. Cow(group), block, group, and block $\times$ group were declared as random variables. To account for autocorrelation of repeated measures on the same experimental unit (cow), we used an $\mathrm{AR}(1)$ error structure.

\section{RESULTS}

\section{Milk Time}

There was moderate evidence of the effect of treatment on milk time (Table 3). Milk time for TRS30 was $9 \mathrm{~s}$ shorter than that for TRS20 $(P<0.01)$, and milking time for TRS50 was $8 \mathrm{~s}$ shorter than that for TRS20 $(P=0.02)$. However, no difference was found between TRS50 and TRS30. Milk yield had a strong influence on milking time $(P<0.0001)$, as did week $(P$ $<0.0001)$.

\section{Box Time}

Similar to milk time, box time was $11 \mathrm{~s}$ shorter for TRS30 than for TRS20. Box time for TRS50 was $9 \mathrm{~s}$ shorter than that for TRS20, with no difference between TRS50 and TRS30 (Table 3$)$. Milk yield $(P<0.0001)$ and week $(P<0.0001)$ also had a strong influence on box time.

\section{$\log _{10}$ SCC}

There was no evidence of a treatment effect on the $\log _{10}$ SCC $(P=0.34$; Table 3$)$. Milk yield $(P<0.0001)$, lactation number $(P=0.01)$, and week $(P<0.0001)$ were associated with $\log _{10}$ SCC.

\section{Average Milk Flow Rate, Maximum Milk Flow Rate, and Milk Production Rate}

There was no effect of treatment on average milk flow rate $(P=0.27)$, maximum milk flow rate $(P=0.45)$, 
or milk production rate $(P=0.2$; Table 3$)$. Similar to milk production rate, milk production per milking and per day were not affected by teatcup removal treatment ( $P=0.3$ and $P=0.8$, respectively). Milk yield had an effect on average flow rate $(P<0.0001)$ but not on maximum milk flow rate $(P=0.16)$. Week had an effect on all 3 of these dependent variables $(P<0.05)$. Because removal settings were applied as a percentage of flow rate, an estimate of the flow rate $(\mathrm{kg} / \mathrm{min})$ at teatcup removal (Table 4) and the distribution of this estimate (Figure 1) were calculated.

\section{DISCUSSION}

We found that milking time was $9 \mathrm{~s}$ longer by taking off the teatcups when quarter milk flow rate fell below $30 \%$ of the average milk flow rate (TRS30) compared with $20 \%$ of the average milk flow rate (TRS20), which represented a $2.6 \%$ reduction in milking time. The dynamics of milk ejection show that as milking progresses, milk flow rate reaches a peak and eventually decreases (Bruckmaier and Hilger, 2001). Our results are in agreement with previous research (Burke and Jago, 2011; Edwards et al., 2013a; Krawczel et al., 2017) where increasing the flow rate at teatcup removal decreases milking time. However, Burke and Jago (2011) showed that an increase in the cluster milk flow switch point from 0.2 to $0.4 \mathrm{~kg} / \mathrm{min}$ resulted in milking times that were $47 \mathrm{~s}$ shorter per cow (11\% reduction), and Edwards et al. (2013a) showed a difference of $40 \mathrm{~s}$ in cluster on time when cluster milk flow switch point was increased from 0.2 to $0.4 \mathrm{~kg} / \mathrm{min}$ (9\% reduction). In AMS, Krawczel et al. (2017) showed that increasing the quarter teatcup milk flow switch point from 0.06 to 0.3 $\mathrm{kg} /$ min reduced milking time by $24 \mathrm{~s}$ ( $5.3 \%$ reduction). In conventional milking, some quarters might have a milk flow rate higher than the set cluster removal flow rate, whereas other quarters might be overmilked. In automatic milking, each quarter is milked up until the teatcup removal flow rate is reached, which could explain why the results in AMS have been lower than in conventional systems. Our estimated milk flow rate at teatcup removal shows that the TRS20 and TRS30 treatments had a lower difference in milk flow rate than previous studies $(0.25 \mathrm{~kg} / \mathrm{min}$ for TRS30 vs. $0.16 \mathrm{~kg} /$ min for TRS20), which could explain the lower milking time difference between these treatments.

The milking time for TRS50 was on average $8 \mathrm{~s}$ shorter than that for TRS20 (2.3\% reduction in milking time). These results are in agreement with Krawczel et al. (2017), where milking time decreased from 7.6 to $6.7 \mathrm{~min}$ by switching from a $0.06 \mathrm{~kg} / \mathrm{min}$ removal setting to a $0.48 \mathrm{~kg} / \mathrm{min}$ setting, which represented a $12 \%$ decrease. No differences in milking times were

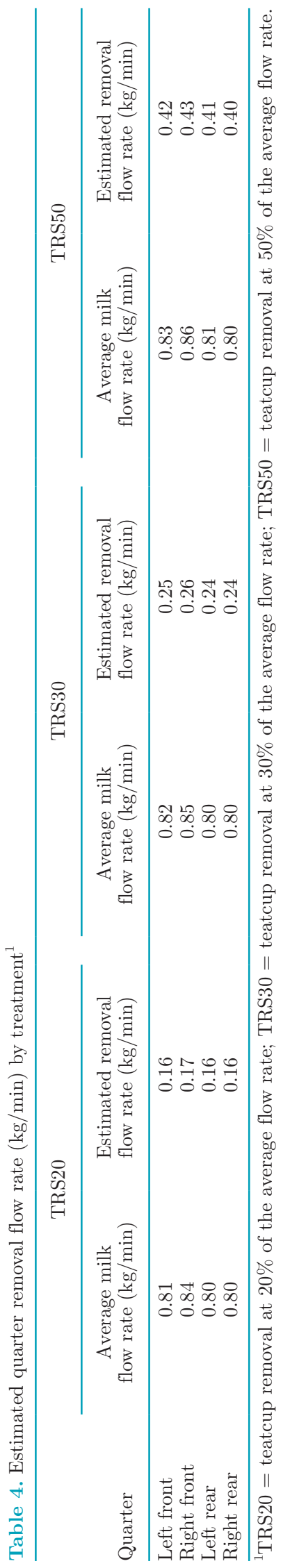

Journal of Dairy Science Vol. 102 No. 9, 2019 


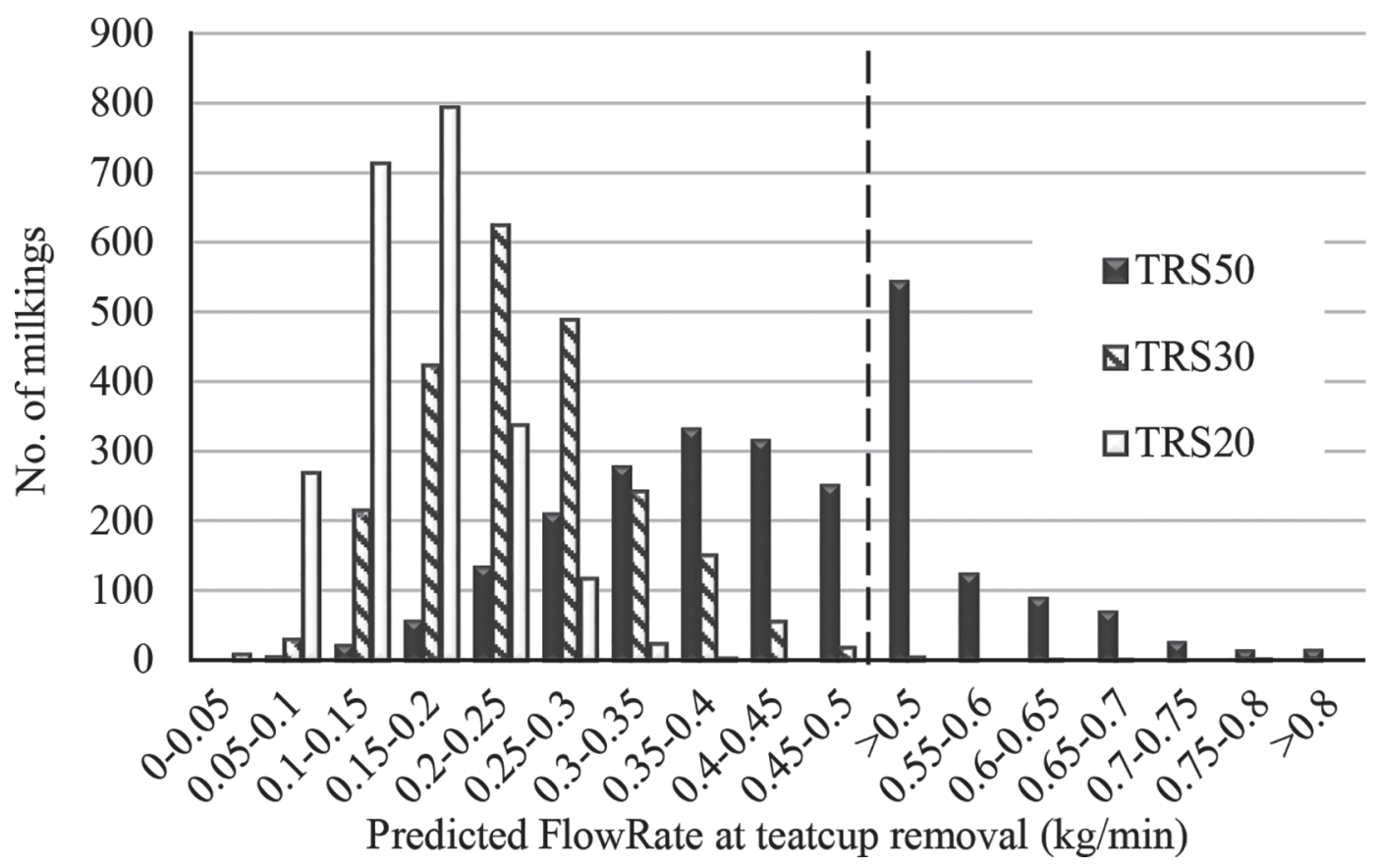

Figure 1. Distribution of the estimated quarter-level flow rates at removal by treatment. The line after the 0.45 to 0.5 mark represents the $0.5 \mathrm{~kg} / \mathrm{min}$ limit for teatcup removal. All milkings to the right of the line would not have received the treatment due to this limit. TRS20 $=$ teatcup removal at $20 \%$ of the average flow rate; TRS30 = teatcup removal at $30 \%$ of the average flow rate; TRS50 = teatcup removal at $50 \%$ of the average flow rate.

found between TRS50 and TRS30. Our estimated flow rate at removal for TRS50 $(0.41 \mathrm{~kg} / \mathrm{min})$ was similar to the $0.48 \mathrm{~kg} / \mathrm{min}$ setting applied in the Krawczel et al. (2017) study. However, the variation in the estimated removal flow rate in our study was very large, from 0.15 to $>0.5 \mathrm{~kg} / \mathrm{min}$ (see Figure 1). This large variation in the estimated milk flow rate at teatcup removal might have affected the magnitude of the effects shown in this study. It is difficult to assess what the results would have been had this limit not been present. Studies in conventional milking (Jago et al., 2010; Edwards et al., 2013a) could serve as a reference; however, milk flow rate at the udder level is a composition of 4 quarters, where 1 or more quarters could have very high milk flow rates, whereas others could have low milk flow rates or be completely milked (Tančin et al., 2007).

To our knowledge, this is the first experiment to evaluate the effect of a percentage based TRS on milking time and milk yield. Using a percentage of the milk flow rate as the criterion for quarter end of milking creates variability in milk flow rate at teatcup removal among cows because low milk flow rate cows might have a calculated milk flow switch point that is very low compared with high milk flow rate cows. This can also produce large variations in the amount of milk that is left in the gland by using these settings and therefore, the effect of the same TRS on milking time and milk yield might be considerably different among cows. Given that teatcup removal is done at the quarter level, the effect on overall milking time is given by the flow rate of the slowest milking quarter. Perhaps this practice would be more successful at reducing milking time when applied at the udder level, were all quarters contribute to the milk flow rate end of milking decision. Further research is necessary to assess the effect of this practice on milking time.

The AMS used in our study applied a $0.5 \mathrm{~kg} / \mathrm{min}$ limit, which prevented removal of a teatcup if the calculated removal flow rate was above this level. This means that the TRS50 removal strategy was limited in its application. In fact, roughly $25 \%$ of the estimated removal flow rates of all quarters milked on the TRS50 setting were above the $0.5 \mathrm{~kg} / \mathrm{min}$ switch point, which prevented teatcup removal with higher milk flow rates. This resulted in a recalculation of the milk flow switch point which possibly led to a lower milk flow switch point than the one originally calculated, thus limiting our ability to assess the real effect of this TRS. This could explain the lack of differences found between the TRS50 and TRS30 treatments. Further research is needed to analyze a 50\% removal strategy without flow rate restrictions to get a sense of the real effect of this practice. The use of a percentage based strategy produces more variability in milk flow rate at teatcup 
removal compared with a strategy that uses absolute milk flow rate $(\mathrm{kg} / \mathrm{min})$ as a decision criteria and could therefore create more uncertainty on the effect of these practice in dairy farms. When deciding on a percentage based criteria for the end of milking these limitations should be taken into account.

The milking robot is constantly milking, and it performs about 140 milkings/d on average. Therefore, by saving $9 \mathrm{~s} /$ milking it is possible to save $21 \mathrm{~min} / \mathrm{d}$, which, by the average of $5.7 \mathrm{~min} /$ milking per cow, would allow over 3 more milkings/d or at least 1 more cow in the robot.

There was no effect of treatment on maximum milk flow or milk production rate. The mechanisms through which milk production is impaired when milking interval is extended or milk is not completely removed from the gland relates to the presence of substances in milk that can reduce the rate of secretion through negative feedback mechanisms (Knight and Dewhurst, 1994). These changes become evident within a few days after initiating once-a-day milking (Knight and Dewhurst, 1994); however, if there is an effect of leaving smaller amounts of milk in the gland on milk production, the speed at which they might become evident has not been reported. The study by Krawczel et al. (2017) on quarter-level TRS in AMS showed no differences in milk production among the 2 teatcup removal strategies when applied for $1 \mathrm{wk}$ each. The study also found that residual milk was not affected by the teatcup removal treatment. Longer-term studies have shown no differences in milk yield when using a $0.8 \mathrm{~kg} / \mathrm{min}$ milk flow switch point compared with $0.2 \mathrm{~kg} / \mathrm{min}$ at the udder level (Edwards et al., 2013a) even though strip yield was $0.3 \mathrm{~kg}$ higher in the $0.8 \mathrm{~kg} / \mathrm{min}$ treatment compared with $0.2 \mathrm{~kg} / \mathrm{min}$. In contrast, the study by Burke and Jago (2011) showed a 1\% reduction in daily milk yield when using a $0.4 \mathrm{~kg} / \mathrm{min}$ versus a 0.2 $\mathrm{kg} / \mathrm{min}$ switch point at the udder level. These differences in milk yield were attributed to the proportion of cows having an udder strip yield higher than $0.5 \mathrm{~L}$ of milk after cluster removal with the $0.4 \mathrm{~kg} / \mathrm{min}$ removal setting, which has been reported as a source of milk production losses (Burke and Jago, 2011). In the paper by Burke and Jago (2011), there is no mention of how soon the differences in milk production became evident. Considering previous literature, it was estimated that 1 wk per treatment period was sufficient to notice changes in milk production associated with teatcup removal, if there were any. One limitation of the present study was the lack of information on quarter strip yield for each treatment, which could have proven useful to further understanding the effects of milk remaining in the gland on milk production.
In contrast with the results from Edwards et al. (2013a), who found a $0.1 \mathrm{~kg} / \mathrm{min}$ difference in average flow rate, no difference was detected in average milk flow rate in our study. A difference in average flow rate could be attributable to greater cisternal milk left from the previous milking, which can be rapidly evacuated from the udder (Edwards et al., 2013a). Given that we detected shorter milking times with no differences in milk yield per milking with the TRS30 and TRS50 settings compared with TRS20, average milk flow rate should have been higher (in fact, it was $0.02 \mathrm{~kg} / \mathrm{min}$ higher for TRS30 and TRS50 compared with TRS20), but the study lacked the power to detect such small differences (our detectable difference was $0.17 \mathrm{~kg} / \mathrm{min}$ ).

No significant treatment effect was seen on the $\log _{10}$ SCC, which was in agreement with Edwards et al. (2013a) and Burke and Jago (2011) in conventional milking systems even though they found higher residual strip yields at the udder level in their studies. Contrary to what many farmers might think, evidence suggests that higher residual milk does not adversely affect SCC (Edwards et al., 2013a). Krawczel et al. (2017) also showed that there was no effect of a $0.48 \mathrm{~kg} / \mathrm{min}$ removal strategy on SCC compared with a $0.06 \mathrm{~kg} / \mathrm{min}$ treatment in an AMS. The duration of the experimental periods in this study may not have allowed enough time to notice changes in SCC, if there were any; however, Stelwagen and Lacy-Hulbert (1996) reported a rapid increase (within $1 \mathrm{~d}$ ) in SCC of cows that were switched from twice-a-day milking to once-a-day milking. This increase reverted back rapidly to previous levels when twice-a-day milking was resumed. Our results suggest that teatcup removal up to $50 \%$ of the average flow rate switch point with a $0.5 \mathrm{~kg} / \mathrm{min}$ limit can be applied without having a negative effect on udder health in this AMS.

The average milking frequency in this study was 1.7 milkings/cow per day. Robotic grazing systems tend to have longer milking intervals and fewer milkings per day than confinement systems (Lyons et al., 2013). The milking frequency in our study was lower than that reported by Lyons and Kerrisk (2017), who found an average of 2.38 milkings per day on 8 Australian farms, but higher than what was found in a pasture-based AMS by Shortall et al. (2018), with 1.4 milkings/cow per day. The research farm in our study had 86 milking cows on 1 robot, which was similar to Shortall et al. (2018) but considerably higher than the average of 51 cows reported by Lyons and Kerrisk (2017), which could explain these differences. This herd averaged 19.3 $\mathrm{kg}$ of milk/d, which is lower than the herd average in the Krawczel et al. (2017) experiment in an indoor AMS and the Edwards et al. (2013a) experiment in a pasture- 
based conventional milking system. Nevertheless, our results are in agreement with what was shown by those experiments, as discussed previously. Higher-yielding herds (e.g., those housed indoors and fed a TMR) may show different responses to these treatments; however, this was outside the scope of our research.

\section{CONCLUSIONS}

Significant reductions in milking time and box time were seen by using a teatcup removal strategy of $30 \%$ (TRS30) and 50\% (TRS50) of the average flow rate compared with $20 \%$ (TRS20) of the average flow rate. No differences in milking time or box time were found between a teatcup removal strategy of 50\% (TRS50) and $30 \%$ (TRS30). This was likely due to large variability in the quarter-level milk flow rate at teatcup removal. This was possibly affected by the great variation in milking interval and thus degree of udder filling. Also, the restriction of $0.5 \mathrm{~kg} / \mathrm{min}$ as a maximum flow rate for teatcup removal could have masked the effect of the $50 \%$ (TRS50) removal strategy on milk time, box time, milk production rate, and SCC compared with the other treatments; however, our implementation of the setting reflects the user experience of the setting, should it be selected by the farmer. This study showed no difference in SCS between the TRS30 and TRS20 teatcup removal strategies. In addition, no differences were seen in milk yield between these treatments.

\section{ACKNOWLEDGMENTS}

Financial support from the Teagasc Walsh Fellowship Programme, the University of Wisconsin-Madison, and Lely (Maassluis, the Netherlands) is gratefully acknowledged. We acknowledge the technical assistance of Caroline O'Sullivan and the staff at the Dairygold research farm at Teagasc Moorepark (Fermoy, Ireland) and the staff at Lely in the design and operation of the experiment. We acknowledge Peter Crump at the Statistical Consulting Group in the College of Agricultural and Life Sciences (Madison, WI) for statistical advice.

\section{REFERENCES}

Bruckmaier, R. M., and M. Hilger. 2001. Milk ejection in dairy cows at different degrees of udder filling. J. Dairy Res. 68:369-376. https:/ /doi.org/10.1017/s0022029901005015.

Burke, J. K., and J. G. Jago. 2011. Comparing somatic cell counts, production and milking durations of dairy cows when milked at two automatic cup-removal flow-rate thresholds. Anim. Prod. Sci. 51:920-924. https://doi.org/10.1071/an11042.

Castro, A., J. M. Pereira, C. Amiama, and J. Bueno. 2012. Estimating efficiency in automatic milking systems. J. Dairy Sci. 95:929-936. https://doi.org/10.3168/jds.2010-3912.

Davis, K., J. Jago, R. Wieliczko, P. Copeman, K. Bright, and M. Woolford. 2005. Factors influencing milk harvesting efficiency in an automatic milking system. Page 271 in Proc. N. Z. Soc. Anim. Prod. New Zealand Society of Animal Production Inc., Hamilton, New Zealand.

Edwards, J. P., J. G. Jago, and N. Lopez-Villalobos. 2013a. Milking efficiency for grazing dairy cows can be improved by increasing automatic cluster remover thresholds without applying premilking stimulation. J. Dairy Sci. 96:3766-3773. https://doi.org/10.3168/ jds.2012-6394.

Edwards, J. P., J. G. Jago, and N. Lopez-Villalobos. 2013b. Shortterm application of prestimulation and increased automatic cluster remover threshold affect milking characteristics of grazing dairy cows in late lactation. J. Dairy Sci. 96:1886-1893. https://doi.org/ $10.3168 /$ jds.2012-6191.

Jago, J. G., J. L. Burke, and J. H. Williamson. 2010. Effect of automatic cluster remover settings on production, udder health, and milking duration. J. Dairy Sci. 93:2541-2549. https://doi.org/10 $.3168 /$ jds.2009-2949.

Knight, C. H., and R. J. Dewhurst. 1994. Once daily milking of dairy cows: Relationship between yield loss and cisternal milk storage. J. Dairy Res. 61:441-449. https://doi.org/10.1017/ s0022029900028363.

Krawczel, P., S. Ferneborg, L. Wiking, T. K. Dalsgaard, S. Gregersen, R. Black, S. Agenäs, K. Svennersten-Sjaunja, and E. Ternman. 2017. Milking time and risk of over-milking can be decreased with early teat cup removal based on udder quarter milk flow without loss in milk yield. J. Dairy Sci. 100:6640-6647. https://doi.org/10 $.3168 /$ jds.2016-12312.

Lyons, N. A., and K. L. Kerrisk. 2017. Current and potential system performance on commercial automatic milking farms. Anim. Prod. Sci. 57:1550-1556. https://doi.org/10.1071/an16513.

Lyons, N. A., K. L. Kerrisk, and S. C. Garcia. 2013. Comparison of 2 systems of pasture allocation on milking intervals and total daily milk yield of dairy cows in a pasture-based automatic milking system. J. Dairy Sci. 96:4494-4504. https://doi.org/10.3168/ jds.2013-6716.

Mollenhorst, H., M. M. Hidayat, J. van den Broek, F. Neijenhuis, and H. Hogeveen. 2011. The relationship between milking interval and somatic cell count in automatic milking systems. J. Dairy Sci. 94:4531-4537. https://doi.org/10.3168/jds.2011-4244.

Penry, J. F., E. L. Endres, B. de Bruijn, A. Kleinhans, P. M. Crump, D. J. Reinemann, and L. L. Hernandez. 2017. Effect of incomplete milking on milk production rate and composition with 2 daily milkings. J. Dairy Sci. 100:1535-1540. https://doi.org/10.3168/jds .2016-11935.

Schalm, O. W., and S. W. Mead. 1943. The effect of incomplete milking on chronic mastitis caused by Streptococcus agalactiae. J. Dairy Sci. 26:823-832. https://doi.org/10.3168/jds.S0022-0302(43)92775 -4 .

Shortall, J., C. Foley, R. D. Sleator, and B. O'Brien. 2018. The effect of dairy cow breed on milk production, cow traffic and milking characteristics in a pasture-based automatic milking system. Livest. Sci. 209:1-7. https://doi.org/10.1016/j.livsci.2018.01.002.

Stelwagen, K., and S. J. Lacy-Hulbert. 1996. Effect of milking frequency on milk somatic cell count characteristics and mammary secretory cell damage in cows. Am. J. Vet. Res. 57:902-905.

Tančin, V., A. H. Ipema, and P. Hogewerf. 2007. Interaction of somatic cell count and quarter milk flow patterns. J. Dairy Sci. 90:22232228. https://doi.org/10.3168/jds.2006-666. 